\title{
Parental Current Practice and Needs in Smart Device Applications for Children with Cochlear Implants
}

\author{
Youngmee Lee \\ Department of Communication Disorders, Tongmyong University, Busan, Korea
}

\section{인공와우 착용 아동 부모의 스마트 기기 이용실태 및 청각재활 콘텐츠 요구도}

이 영 미

동명대학교 언어치료학과

\begin{abstract}
Purpose: The purpose of present study was 1) to investigate the current practice and participation of parents in auditory rehabilitation for children with cochlear implants (Cls), and 2) to suggest for developing the contents of smart device applications as a tool of their auditory rehabilitation. Methods: A questionnaire was developed to examine the current practice, participation, and needs of smart device applications in auditory rehabilitation and background information. Seventy-seven parents of children with Cls participated in the survey. Results: The parents most frequently used the smartphones for their daily lives and improvement of their children's auditory performance, followed by tablet PCs and smart TVs. They also allowed children with Cls to use smart devices in order to respond to their children's requests, to let the children learn something, and to soothe children's temper tantrums. The parents highly desired smart device applications of auditory habilitation for children with $\mathrm{Cls}$, and there was not a significant difference between groups (infants, preschoolers, schoolers) and types of contents (auditory skills, auditory-language skills, parental education). Conclusion: The results demonstrated that parents were very interested in the possibility of using smart device applications as a tool for improving auditory performance of their children. The current results suggest that parents have needs to receive the auditory rehabilitation services via the smart device applications of their children with Cls.
\end{abstract}

Key Words: Cochlear implants, Parents for children with cochlear implants, Children with cochlear implants, Smart applications.

Received: September 24, 2016 / Revised: October 10, 2016 / Accepted: October 11, 2016

Correspondence: Youngmee Lee, Department of Communication Disorders, Tongmyong University, 428 Sinseon-ro, Nam-gu, Busan 48520, Korea Tel: +82-51-629-2135 / Fax: +82-51-629-2019 / E-mail: ymlee3060@gmail.com

\section{INTRODUCTION}

인공와우이식(cochlear implantation)은 보청기를 착용하여 도 듣기에 어려움을 지니는 양측 고도 이상의 청각장애인의 달 팽이관 속에 미세한 전극을 삽입하여 전기적인 자극을 청신경 에 전달해서 소리를 감지하도록 하는 수술이다(Cole \& Flexer, 2011). 인공와우이식은 고도 이상의 청각장애인에게 유용한 청 력을 제공함으로써 효과적이고 안전한 청각재활 방법으로 확 고한 위치를 차지하였다(Nikolopoulos et al., 2003). 특히, 초기 에는 성인에게만 허용되었던 인공와우이식이 2002년부터 미국 식품의약안전청의 승인으로 만 1 세의 영유아까지 그 범위가 확
대됨으로써, 조기 인공와우이식으로 청각장애 아동의 말지각, 말, 언어 발달에 긍정적인 영향을 미치게 되었다(ASHA, 2016; Cole \& Flexer, 2011). 청각장애 아동이 경험하는 청각박탈 기 간 동안의 말-언어 지연과 인공와우로 전달되는 제한적인 청각 정보를 보완하기 위해서는 인공와우이식 전, 후에 적극적이고 집중적인 청각재활(auditory rehabilitation)이 이루어져야 원활 한 구어 의사소통(oral communication) 발달이 가능하다.

국내외에서 청각재활은 조기에 난청이 진단되면 청각재활 전 문가가 주 1 2회, 40 90분의 시간 동안 부모에게 의사소통 방 법, 청각, 말, 언어 및 정서 발달, 상호작용 등의 정보를 제공하 는 형태로 진행된다. 청각재활 전문가는 다양한 검사도구를 사 
용하여 청각장애 아동의 수행력을 평가하고, 직접적인 상호작 용을 통한 모델링과 촉진, 부모가 가정에서도 청각장애 자녀를 교육할 수 있도록 부모에게 간접 교육을 제공한다(Lee, 2008). 즉, 청각재활은 청각장애 아동이 청력 손실로 발생될 수 있는 말, 언어, 의사소통에서의 불이익을 최소화하며, 일상생활에서 의 원활한 의사소통을 하여 사회에 잘 적응하는 성인으로 성 장할 수 있도록 한다(ASHA, 2016; Yu et al., 2014). 궁극적으 로 인공와우 아동의 특성에 따른 단계적이고 체계적인 청각재 활이 지속적으로 이루어져야 인공와우로부터 들어오는 청각 정보를 충분히 활용하여 정상적인 말, 언어 발달이 이루어질 수 있는 것이다.

최근에는 다양한 디지털 기기의 증가와 스마트폰 사용자 수 가 증가되어, 시공간 제약 없이 다양한 자료를 제시하고 콘텐츠 와 상호작용하는 등의 개별화된 학습 기회를 제공하는 스마트 러닝에 대한 관심이 증대되었다(Lee, 2010; Lee \& Sung, 2015). 스마트 러닝은 일반인을 대상으로 하는 일반교육에만 한정되지 않고 있으며, 교육과학기술부가 2011년에 장애 학생을 위한 스 마트러닝 추진안을 발표하면서 장애 학생을 위한 어플리케이션 (application, 앱) 개발에 대한 관심이 특수교육 분야에서도 높 아지고 있다(Lim \& Park, 2012). 의료와 언어치료 분야에서도 스마트 기기를 통해 질병이나 장애의 선별 진단, 치료 가이드라 인의 제공, 재활 지원 등의 헬스 케어, 스마트 재활 도구의 측면 에서 앱 활용에 대해 모색하고 있다(Im et al., 2013; Lee et al., 2013; Yim et al., 2014).

국내에서는 스마트 기기가 이동통신사업의 발전과 함께 짧 은 시간 안에 성능과 기능이 급성장하여 스마트 기기의 보급률 이 높은 특징을 보이고 있다. 앱은 스마트 기기와 결합으로 개 인이 원하는 맞춤 콘텐츠 제공이 가능한 특징을 지니고 있기 때문에, 수요와 공급이 지속적으로 증가하는 추세이다(Hwang \& So, 2016; Lee \& Sung, 2015; Yim et al., 2014). 이러한 흐름 은 자연스럽게 청각재활 분야에도 이어져서 청각장애인을 위한 앱 개발과 활용에 대한 관심도 높아졌다. 이에 따라 청각재활 콘텐츠의 스마트폰 앱을 청각재활에 적용한 연구 사례가 최근 에 보고되고 있다(Lee \& Lee, 2016; Yu et al., 2014). Yu et al. (2014)이 보청기를 착용한 성인( $\mathrm{n}=1)$ 에게 스마트폰 앱을 이용 하여 4주간 청각재활을 실시한 결과, 중재 후의 자음 검사와 문 장인지검사 점수가 중재 전에 비해서 유의하게 향상되었다. Lee \& Lee(2016)는 취학 전 인공와우 아동 $(\mathrm{n}=3)$ 에게 청각기 억 향상을 위해 개발한 앱을 이용하여 4주간 중재를 실시하였 다. 그 결과, 중재 기간 동안 인공와우 아동의 청각 기억이 지속 적으로 향상되었으며, 중재 후의 청각 기억 검사 점수가 중재 전에 비해서 유의하게 향상되었다. 이러한 긍정적인 중재 효과 에 대한 보고는 임상 현장에서 다양한 스마트 기기와 미디어
매체를 활용하는 등으로 청각재활 중재의 다변화에 영향을 미 칠 것으로 보여진다.

컴퓨터를 이용한 중재(computer-assisted instruction)를 인 공와우나 보청기를 착용한 청각장애 아동에게 적용한 결과, 컴 퓨터 소프트웨어는 청각장애 아동의 음운처리, 철자, 읽기 발달 에 도움을 주는 것으로 나타났다(Fu \& Galvin, 2007; Nekeva von Mentzer et al., 2013, 2014). 컴퓨터를 이용한 중재는 시간 적 제한의 극복은 가능하나 공간적 제한은 극복하지 못하는 한계점이 있으며, 소프트웨어의 높은 가격으로 임상 현장과 가 정에서는 보편적으로 사용하기 어려운 단점이 있다(Yim et al., 2014; Yu et al., 2014). 즉, 사용자는 시간에 관계없이 소프트웨 어를 컴퓨터에서 실행시킬 수 있지만, 장소 이동 중이나 협소한 공간에서 소프트웨어를 컴퓨터에서 사용하기에는 불편함이 발 생된다. 반면에, 스마트 기기는 컴퓨터보다 작아서 휴대하기 간 편하며, 시공간을 초월하여 사용할 수 있고, 터치로 쉽게 조작 이 가능하다. 또한, 스마트 기기의 기술 발달로 청각재활 콘텐 츠를 그림, 글자, 음성, 동영상, 애니메이션 등의 다양한 표현 양 식(modality)으로 구현이 가능하다. 스마트 기기의 성능과 기능 의 장점을 살린 청각재활 앱 콘텐츠를 저렴한 가격으로 제공한 다면, 부모가 일상생활에서 인공와우 아동의 말, 언어 촉진에 도움을 주고 청각재활 전문기관이 부재한 지역에 거주하는 인 공와우 아동도 보완적인 혜택을 누릴 수 있을 것이다. 스마트 기기와 앱이 청각재활 분야에 적극적으로 활용되어 임상 현장 의 전문가와 부모가 인공와우 아동의 말지각, 말, 언어 발달의 도구로 사용되도록 하기 위해서는 실수요자라고 할 수 있는 인 공와우 아동의 부모의 스마트 기기 이용 실태와 실제적인 수요 도에 대한 기초 연구가 필요하다. 즉, 인공와우 아동의 청각재 활에 필요한 콘텐츠를 개발하고 일상생활 통합형 청각재활 지 원 서비스를 스마트 기기를 통해서 제공하기 위해서는 실수요 자의 현황과 요구를 파악할 필요가 있다. 인공와우 아동의 경 우는 직접 설문조사를 진행하여 신뢰로운 자료를 얻기 힘들기 때문에, 간접치료의 대상이 되는 부모를 대상으로 설문조사를 진행하여 환경과 요구 파악이 선행되어야 한다.

본 연구에서는 인공와우 아동 부모의 스마트 기기 활용 실태 를 살펴보고, 부모가 자녀의 스마트 기기 이용에 대한 참여도 가 어떠한지 알아보고자 하였다. 나아가 인공와우 아동의 연령 대에 따라서 필요로 하는 청각재활 관련 콘텐츠의 유형과 요구 도를 조사하여, 스마트 기기를 통해 인공와우 아동의 일상생활 과 통합된 형태의 청각재활 서비스의 지원 가능성에 대해서 모 색해보았다. 이를 위한 구체적인 연구 질문은 다음과 같다.

첫째, 인공와우 아동 부모의 스마트 기기 활용도는 어떠한가?

둘째, 인공와우 아동의 스마트 기기 이용에 대한 부모 참여 도는 어떠한가? 
셋째, 인공와우 아동의 연령대(영유아기, 학령전기, 학령기)와 청각재활 앱 콘텐츠 유형에 따른 요구도에 유의한 차이를 보이 는가?

\section{MATERIALS AND METHODS}

\section{연구 대상}

본 연구의 대상자는 부산 지역에 소재한 청각재활 교육기관 에서 언어치료를 받고 있는 인공와우 아동의 부모 67 명이었다. 이원혼합배치 분산분석을 위한 적절한 대상자의 수를 산출하 기 위해서 $G^{*}$ Power 프로그램(Faul et al., 2009)을 이용하여 검증력 0.95 , 유의수준 0.05 (양측검증), 효과크기 0.25 으로 대상 자의 수를 산출한 결과, 총 55 명 이상의 대상자가 필요한 것으 로 나타났다. 불성실한 응답, 미응답 등을 고려하여 총 90 부의 설문지를 배포하였으며, 그 중 75 부(83.3\%)를 회수하였다. 설문 에 참여한 75 명 중 불성실하게 작성된 8 명의 설문지를 제외한 67명(74.4\%)의 설문지를 분석하였다. 대상자에 대한 구체적인 정보는 Table 1 과 같다. 대상자에서 아버지가 응답한 비율은 $16.4 \%$, 어머니가 응답한 비율은 $79.1 \%$ 기타(조부모, 이모 등의 주양육자)가 응답한 비율은 $4.5 \%$ 였다. 인공와우 아동의 평균 연 령은 6.57 세 $(\mathrm{SD}=3.27)$ 였으며, 성별은 남아가 $62.7 \%$, 여아가 $37.3 \%$ 였다. 인공와우 아동의 아버지의 평균 연령은 41.34 세(SD $=4.83)$ 였고, 어머니의 평균 연령은 38.39세 $(\mathrm{SD}=4.865)$ 였다. 인 공와우 아동 중에서 중복장애를 지니고 있는 경우가 $17.9 \%$ 였으 며, 중복장애 유형으로는 언어발달장애(13.4\%), 지적장애(3.0\%), 지체장애(1.5\%)로 나타났다.

\section{연구 도구}

설문지는 1) 인공와우 아동 부모의 스마트 기기 이용실태(10 문항), 2) 인공와우 아동의 스마트 기기 사용에서 부모의 참여 도(10문항), 3) 필요로 하는 청각재활 앱 콘텐츠 유형(14문항), 4) 대상자의 기본 정보(11문항)를 묻는 네 영역, 총 45 문항으로 구성하였다. 이때, 청각재활과 관련된 앱 콘텐츠 요구도에는 앱 을 이용한 청각재활의 교육 효과, 초기 청각 발달(감지 및 확 인), 청각-언어 발달, 청각재활 관련 정보 제공 및 공유에 관한 문항으로 구성하였다. 대상자의 인구사회학적 특성 및 기본 정 보를 묻는 11 개의 문항은 설문지의 가장 마지막에 배치하여 설 문 응답자의 부담을 줄이고자 하였으며, 응답자의 사생활 침해 가 적도록 자기 기입식의 문항으로 구성하였다. 설문 문항의 반 응 유형은 주로 선택형과 척도형으로 구성하였으며, 앱 요구도 와 관련된 문항은 '전혀 필요 없다(1점)'에서 '매우 필요하다(5 점)'에 이르기까지 5점 척도를 이용하여 표시하도록 하였다. 인 공와우 아동의 청각재활에 필요한 콘텐츠 유형에 대해서는 단
Table 1. Participants' information

\begin{tabular}{|c|c|}
\hline Classification & Frequency (\%) \\
\hline \multicolumn{2}{|l|}{ Relationship with a child } \\
\hline Father & $11(16.4)$ \\
\hline Mother & $53(79.1)$ \\
\hline Others & $3(4.5)$ \\
\hline \multicolumn{2}{|l|}{ Father's age } \\
\hline $30-34$ & $7(10.4)$ \\
\hline $35-39$ & $19(28.4)$ \\
\hline $40-44$ & $21(31.3)$ \\
\hline $45-49$ & $18(26.9)$ \\
\hline$\geq 50$ & $2(3.0)$ \\
\hline \multicolumn{2}{|l|}{ Mother's age } \\
\hline$\leq 30$ & $3(4.5)$ \\
\hline $30-34$ & $12(17.9)$ \\
\hline $35-39$ & $24(35.8)$ \\
\hline $40-44$ & $21(31.4)$ \\
\hline $45-49$ & $7(10.4)$ \\
\hline \multicolumn{2}{|l|}{ Sex of a child } \\
\hline Male & $42(62.7)$ \\
\hline Female & $25(37.3)$ \\
\hline \multicolumn{2}{|l|}{ Age of a child (yr) } \\
\hline$<3$ & $20(29.9)$ \\
\hline $3-7$ & $25(37.3)$ \\
\hline $8-13$ & $22(32.8)$ \\
\hline \multicolumn{2}{|c|}{ Types of multiple disabilities (multiple responses) } \\
\hline $\mathrm{HI}$ & $67(100)$ \\
\hline ID & $2(3.0)$ \\
\hline $\mathrm{PD} / \mathrm{CP}$ & $1(1.5)$ \\
\hline $\mathrm{LD}$ & $9(13.4)$ \\
\hline \multicolumn{2}{|c|}{ Education experiences (multiple responses) } \\
\hline ST & $67(100)$ \\
\hline PT & $8(11.9)$ \\
\hline AT & $14(20.9)$ \\
\hline OT & $4(6.0)$ \\
\hline LT & $5(7.5)$ \\
\hline SIT & $4(6.0)$ \\
\hline
\end{tabular}

HI: hearing impairment, ID: intellectual disabilities, PD/CP: physical disabilities or cerebral palsy, LD: language disabilities, ST: speech therapy, PT: play therapy, AT: art therapy, OT: occupational therapy, LT: learning therapy, SIT: sensory integration therapy

일 응답뿐만 아니라 기술형 응답도 가능하도록 하였다.

선행연구 및 기존 자료(Korea Information Society Development Institute, 2011; Korea Internet \& Security Agency, 2015; Kwak \& Lim, 2013; Lee \& Lee, 2014; Lee \& Sung, 2015; Lee et al., 2013; Ryu, 2014; Yim et al., 2014)를 참고로 부모의 스마트 기기 이용 실태, 인공와우 아동의 스마트 기기의 사용에서 부모의 참여, 청각재활 관련 앱 콘텐츠 요구도의 내 용으로 1차로 설문지를 개발하였다. 해당 설문지를 언어병리학 
교수 1 인과 청각재활 언어치료사 1 인에게 내용의 타당성과 문 항의 적절성을 검증받아서, 부적절한 용어나 문장을 수정하고 중복되는 문항을 통합하였다. 수정된 2차 설문지를 언어치료사 2 인과 인공와우 아동의 어머니 2 인에게 사전 검사하여, 최종적 으로 설문지의 문항과 구성을 개선하였다. 대상자가 설문지를 작성하는 데 필요한 시간은 약 10 15분 정도였으며, 본 연구에 서 사용된 설문지의 문항 일부를 Appendix에 제시하였다.

\section{연구 절차}

설문 조사 기간은 2016년 5월 10일부터 7월 30일까지 약 3개 월 실시하였으며, 부산 지역 내 청각재활 교육기관의 담당자, 언 어치료사에게 연구 협조문을 이메일로 발송하고, 전화로 연구 의 목적과 내용에 대해서 설명하였다. 설문조사 협조가 가능한 세 곳의 교육기관에 조사 일정에 따라서 연구원 2명이 직접 방 문하여 인공와우 아동의 부모를 대상으로 일대일 대면 방식으 로 설문조사를 실시하였다. 연구원은 대상자에게 연구 목적과 내용을 직접 설명하였으며, 설문 참여에 동의한 경우에 설문지 를 전달하여 작성하도록 하였다. 대상자가 설문 작성을 중도에 포기하기를 원하면 중단하도록 하였으며, 설문지의 회수는 연 구원이 직접 회수하였다. 설문에 참여한 총 75 명 중에서 불성실 하거나 미비한 응답을 제외한 67 명의 설문 자료를 분석하였다.

\section{통계 분석}

본 연구에서 수집된 자료 분석을 위해서 IBM SPSS Statistics version 22 (IBM Co., Armonk, NY, USA)를 이용하였다. 대상자의 기본 정보 및 설문 응답에 대해서 빈도와 백분율을 산출하였으며, 다중응답 문항에 대해서는 케이스백분율을 산 출하였다. 집단과 앱 콘텐츠 유형에 따른 응답의 차이를 분석하 기 위해서 이원혼합분산분석(two-way mixed ANOVA)을 실 시하였다.

\section{RESULTS}

\section{인공와우 아동 부모의 스마트 기기 이용실태}

인공와우 아동의 부모에게 스마트 기기의 이용실태를 살펴 본 결과는 Table 2에 정리하였으며, 복수응답을 허용한 문항에 대해서는 빈도, 백분율 외에도 케이스백분율도 함께 제시하였 다. 인공와우 아동의 부모가 사용하고 있는 스마트 기기(복수 응답 허용)에는 스마트폰(94.0\%), 태블릿 $\mathrm{PC}(50.7 \%)$, 스마트 $\mathrm{TV}(29.9 \%)$ 순으로 나타났다. 스마트 기기를 사용하는 목적(복 수응답 허용)에는 정보검색(83.6\%), 커뮤니케이션(83.6\%), 여가 (80.6\%), 쇼핑(62.7\%)이 높게 나타났으며, 스마트 기기를 이용하 는 장소(복수응답 허용)에는 가정(88.1\%), 교통수단 안(47.8\%),
Table 2. Current practice of using the smart devices of parents

\begin{tabular}{|c|c|c|c|}
\hline Classification & Details & $\mathrm{n}(\%)$ & Case \% \\
\hline \multirow[t]{3}{*}{ Types* } & Smartphone & $63(53.8)$ & 94.0 \\
\hline & Tablet PC & $34(29.1)$ & 50.7 \\
\hline & Smart TV & $20(17.1)$ & 29.9 \\
\hline \multirow[t]{8}{*}{ Purposes* } & Information & $56(17.4)$ & 83.6 \\
\hline & Education \& Learning & $35(10.9)$ & 52.2 \\
\hline & Communication & $56(17.4)$ & 83.6 \\
\hline & Work & $15(4.7)$ & 22.4 \\
\hline & Leisure \& Hobby & $54(16.8)$ & 80.6 \\
\hline & Location based services & $29(9.0)$ & 43.3 \\
\hline & Shopping & $42(13.0)$ & 62.7 \\
\hline & Financial services & $35(10.9)$ & 52.2 \\
\hline \multirow[t]{7}{*}{ Location* } & Home & $59(33.3)$ & 88.1 \\
\hline & Work places & $16(9.0)$ & 23.9 \\
\hline & Child's education institute & s $19(10.7)$ & 28.4 \\
\hline & Transportation & $32(18.1)$ & 47.8 \\
\hline & Commercial facilities & $25(14.1)$ & 37.3 \\
\hline & Outdoors & $16(9.0)$ & 23.9 \\
\hline & Public facilities & $10(5.6)$ & 14.9 \\
\hline \multirow[t]{4}{*}{ Frequency } & Everyday & $62(92.5)$ & \\
\hline & $1-2$ times per week & $1(1.5)$ & \\
\hline & $3-4$ times per week & $2(3.0)$ & \\
\hline & $5-6$ times per week & $2(3.0)$ & \\
\hline \multirow[t]{5}{*}{ Hours of use } & $<1$ hour & $9(13.4)$ & \\
\hline & $1-2$ hours & $19(28.4)$ & \\
\hline & $2-3$ hours & $21(31.3)$ & \\
\hline & $4-5$ hours & $14(20.9)$ & \\
\hline & $>5$ hours & $4(6.0)$ & \\
\hline \multirow[t]{9}{*}{ Numbers of apps } & Smartphone & & \\
\hline & $<25$ apps & $39(58.2)$ & \\
\hline & $25-50$ apps & $18(26.9)$ & \\
\hline & 50-75 apps & $8(11.9)$ & \\
\hline & $75-100$ apps & $2(3.0)$ & \\
\hline & Tablet PC & & \\
\hline & $<25$ apps & $39(58.2)$ & \\
\hline & $25-50$ apps & $6(9.0)$ & \\
\hline & $50-75$ apps & $2(3.0)$ & \\
\hline \multirow{2}{*}{$\begin{array}{l}\text { Experiences using apps } \\
\text { for aural rehabilitation }\end{array}$} & Experienced person & $39(58.2)$ & \\
\hline & Inexperienced person & $28(41.8)$ & \\
\hline
\end{tabular}

${ }^{*}$ Multiple answer

상업시설(37.3\%) 순서로 나타났다. 스마트 기기의 사용 빈도는 '매일 사용한다(92.5\%)'는 응답이 절대적으로 높았으며, 하루 이용 시간에는 '2 3시간(31.3\%)'이 가장 높게 나타났다.

스마트 기기에 설치한 앱 개수는 스마트폰과 태블릿 $\mathrm{PC}$ 모 두 25개 미만(58.2\%)으로 높게 나타났으며, 최근 1개월 내에 이 용한 앱 개수는 스마트폰은 5 10개(41.8\%), 태블릿 PC에서는 5 개 미만(71.7\%)이 가장 높았다. 부모의 58.2\%(39명)는 인공와 우 아동을 위해서 앱을 사용해본 경험이 있다고 응답하였으며, 
이들은 인터넷(45\%), 전문가(30\%), 앱 마켓(27.5\%), 책(10.0\%)을 통해서 앱을 이용하게 되었다고 하였다. 부모의 $41.8 \%$ (28명)는 앱을 사용한 경험이 없다고 응답하였으며, 사용하지 않는 이유 (복수응답 허용)로는 정보 부족(53.3\%), 교육효과에 대한 의구 심(30.0\%), 장애 특성이 반영되지 않은 콘텐츠(23.3\%) 순서로 응답하였다.

\section{스마트 기기 이용에 대한 부모 참여도}

인공와우 아동의 스마트 기기 이용과 부모 참여에 대한 결과 는 Table 3에 제시하였다. 인공와우 아동의 스마트 기기의 사용 여부에 관한 질문에 인공와우 아동의 $73.1 \%$ (49명)가 스마트 기 기를 사용하고 있었으며, $26.9 \%$ (18명)는 스마트 기기를 사용하 지 않는다고 응답하였다. 인공와우 아동에게 스마트 기기를 사 용하게 하는 이유(복수응답 허용)로는 '자녀가 원해서(60.7\%)'

Table 3. Parents' participation and support in using the smart devices for children with cochlear implants

\begin{tabular}{|c|c|c|c|}
\hline Classification & Details & $\mathrm{n}(\%)$ & Case \% \\
\hline \multirow[t]{2}{*}{ Child's use of smart devices } & Use & $49(73.1)$ & \\
\hline & Useless & $18(26.9)$ & \\
\hline \multirow[t]{5}{*}{ Purposes of using the smart devices of children* } & To feel funny & $34(42.5)$ & 60.7 \\
\hline & To comfort a crying/annoying child & $9(11.3)$ & 16.1 \\
\hline & To stop child interrupting parents & $6(7.5)$ & 10.7 \\
\hline & To learn something new & $29(36.3)$ & 51.8 \\
\hline & Others & $2(2.5)$ & 3.6 \\
\hline \multirow[t]{3}{*}{ Reasons not to allow a child to use the smart devices* } & Vague concern & $43(79.6)$ & 84.3 \\
\hline & Child's indifferences of the devices & $3(5.6)$ & 5.9 \\
\hline & Others & $8(14.8)$ & 15.7 \\
\hline \multirow[t]{5}{*}{ Support* } & Do not help a child with anything & $13(17.1)$ & 22.0 \\
\hline & Help a child when he/she selects apps & $9(11.8)$ & 15.3 \\
\hline & Help their child when they ask for help & $19(25.0)$ & 32.2 \\
\hline & Use the apps together with a child & $16(21.1)$ & 27.1 \\
\hline & Watch a child using the apps & $19(25.0)$ & 32.2 \\
\hline \multirow[t]{12}{*}{ Numbers of apps for a child } & Smartphone & & \\
\hline & $<5$ apps & $50(74.6)$ & \\
\hline & $5-10$ apps & $10(14.9)$ & \\
\hline & $10-15$ apps & $2(3.0)$ & \\
\hline & $15-20$ apps & $1(1.5)$ & \\
\hline & $20-25$ apps & $2(3.0)$ & \\
\hline & Table PC & & \\
\hline & $<5$ apps & $35(52.2)$ & \\
\hline & $5-10$ apps & $5(7.5)$ & \\
\hline & $10-15$ apps & $3(4.5)$ & \\
\hline & $15-20$ apps & $1(1.5)$ & \\
\hline & $20-25$ apps & $1(1.5)$ & \\
\hline \multirow[t]{3}{*}{ Attitudes for searching apps for a child } & Active & $5(7.4)$ & \\
\hline & Neutral & $32(47.8)$ & \\
\hline & Passive & $30(44.8)$ & \\
\hline \multirow[t]{2}{*}{ Experiences to buy the paid apps } & Experienced person & $15(22.4)$ & \\
\hline & Inexperienced person & $52(77.6)$ & \\
\hline \multirow[t]{7}{*}{ Types of child's apps* } & Game & $36(18.1)$ & 53.7 \\
\hline & Learning & $28(14.1)$ & 41.8 \\
\hline & Narration of the fairy tale & $16(8.0)$ & 23.9 \\
\hline & Electric books & $4(2.0)$ & 6.0 \\
\hline & Children's song & $30(15.1)$ & 44.8 \\
\hline & Animation & $43(21.6)$ & 64.2 \\
\hline & Taking pictures & $42(21.1)$ & 62.7 \\
\hline
\end{tabular}

*Multiple answer 
가 가장 높았으며, 그 다음으로는 '자녀의 교육, 학습을 위해서 (51.8\%)'였다. 인공와우 아동에게 스마트 기기를 사용하지 않게 하는 이유(복수응답 허용)로는 '스마트 기기가 자녀에게 좋지 않을 것 같아서(84.3\%)'가 가장 높게 나타났다.

인공와우 아동의 부모는 자녀가 스마트 기기를 사용하는 동 안 도움을 주는 형태를 살펴보면, '자녀가 도움을 요청할 때만 도움을 준다(25.0\%)'나 '자녀가 앱을 사용하는 것을 지켜본다 (25.0\%)'와 같이 수동적인 도움을 주는 경우가 많았으며, 그 다 음으로는 '자녀와 함께 앱을 이용하면서 지도한다(27.1\%)'가 많 이 나타나서 부모가 인공와우 아동의 스마트 기기 활용에 도움 을 주는 경우도 높은 비율을 차지하고 있었다. 인공와우 아동 이 스마트 기기를 사용한 후의 부모 참여에 관한 질문에서는 '자녀와 함께 앱에 대해서 이야기한다(36.8\%)', '아무런 역할을 하지 않는다(32.4\%)', '관련된 앱을 찾아준다(23.5\%)'와 같은 응 답이 높게 나타났다.

부모가 인공와우 아동이 사용하는 목적으로 설치해놓은 앱 개수를 살펴보면, 스마트폰에서는 '5개 미만(74.6\%)', 태블릿 PC 에서는 '5개 미만(52.2\%)'이 높게 나타났다. 부모는 인공와우 아 동이 할 수 있는 앱을 검색하는 데 들이는 노력은 보통(47.8\%) 이거나 소극적(44.8\%)이라고 응답한 비율이 높았으며, 인공와 우 아동을 위해서 유료 앱을 구매한 경험이 있는 부모는 22.4\%(15명)였다. 그리고 인공와우 아동이 사용하는 앱 유형 (복수응답 허용)은 애니메이션 시청(64.2\%), 사진 및 동영상 촬 영(62.7\%), 게임(53.7\%), 동요(44.8\%), 학습(41.8\%), 동화구연 (23.9\%), 전자책(6\%) 순서였다.

\section{청각재활 콘텐츠 요구도}

인공와우 아동의 청각 수행력 향상을 위해서 개발된 앱의 교 육효과에 대해서 묻는 질문에 부모의 91.0\%(61명)가 “예”라고 응답을 해서, 청각재활 앱이 자녀의 청각 수행력 향상에 긍정적
인 효과가 있을 것으로 생각하고 있었다. 단지 부모의 9.0\%(6 명)만이 청각재활 앱이 자녀의 청각 수행력 향상에 도움이 되 지 않을 것으로 생각하고 있었다. 인공와우 아동의 청각재활과 관련된 앱 콘텐츠에 대한 연령대별 집단(영유아, 학령전기, 학령 기)의 요구를 알아본 결과는 Table 4 와 Figure 1에 제시하였다. 전체적으로는 '말소리를 듣고 어휘를 학습할 수 있는 콘텐츠 (앱3)', ‘청각기억력을 향상시킬 수 있는 콘텐츠(앱4)', ‘이야기를 듣고 질문에 대답할 수 있게 하는 콘텐츠(앱5)', '소리-반응 기 술을 연습하는 콘텐츠(앱7)'에 대한 요구가 높게 나타났다. 본 설문에서 제시한 12 개의 앱 유형에 대한 콘텐츠의 요구도는 세 집단 모두에서 평균 4.0 이상으로 나타나서, 청각재활 앱 콘텐 츠에 대한 요구도가 높다는 것을 확인하였다.

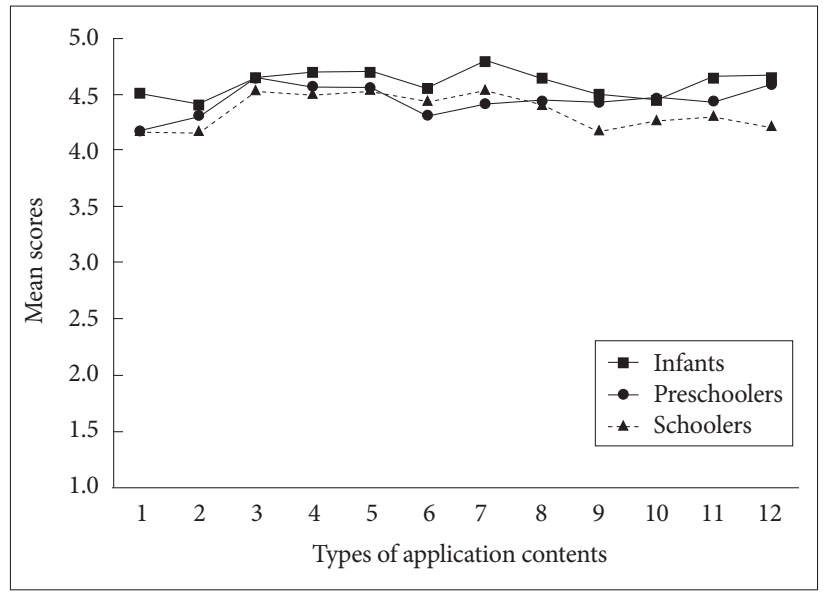

Figure 1. Parents' desired auditory rehabilitation contents in smart device applications. 1: to recognize environmental sounds, 2: to identify familiar words, 3: learn age-appropriate words by listening, 4: to improve auditory memory, 5 : to improve comprehension skills about the wh-questions, 6: to improve listening skills in noise, 7 : to improve conditioned auditory-response skills, 8: to practice familiar phrases and sentences, 9: to use the program to synthesize the text to sppech, 10: to listen to lectures from professionals, 11: to attend the parental education, 12: to share the information about a child's performance.

Table 4. Mean and standard deviation of needs for a smart device application based on the groups

\begin{tabular}{rlccc}
\hline \multicolumn{1}{c}{ Questions } & Infants $(\mathrm{n}=20)$ & Preschoolers $(\mathrm{n}=25)$ & Schoolers $(\mathrm{n}=22)$ \\
\hline 1 & To recognize environmental sounds & $4.50(0.688)$ & $4.16(0.850)$ & $4.18(0.733)$ \\
2 & To identify familiar words & $4.40(0.681)$ & $4.32(0.690)$ & $4.18(0.795)$ \\
3 & To learn age-appropriate words by listening & $4.65(0.489)$ & $4.64(0.490)$ & $4.55(0.510)$ \\
4 & To improve auditory memory & $4.70(0.571)$ & $4.56(0.507)$ & $4.50(0.512)$ \\
5 & To improve comprehension skill about the wh-questions & $4.70(0.571)$ & $4.56(0.507)$ & $4.50(0.596)$ \\
6 & To improve listening skills in noise & $4.55(0.686)$ & $4.32(0.802)$ & $4.45(0.596)$ \\
7 & To improve conditioned auditory-response skills & $4.80(0.410)$ & $4.42(0.654)$ & $4.55(0.510)$ \\
8 & To practice familiar phrases and sentences & $4.65(0.489)$ & $4.44(0.712)$ & $4.41(0.666)$ \\
9 & To use the program to synthesize the text to speech & $4.50(0.761)$ & $4.44(0.712)$ & $4.18(0.958)$ \\
10 & To listen to lectures from professionals & $4.45(0.826)$ & $4.48(0.653)$ & $4.27(0.767)$ \\
11 & To attend the parental education & $4.65(0.489)$ & $4.44(0.651)$ & $4.32(0.716)$ \\
12 & To share the information about a child's performance & $4.65(0.587)$ & $4.60(0.577)$ & $4.23(0.685)$ \\
\hline
\end{tabular}




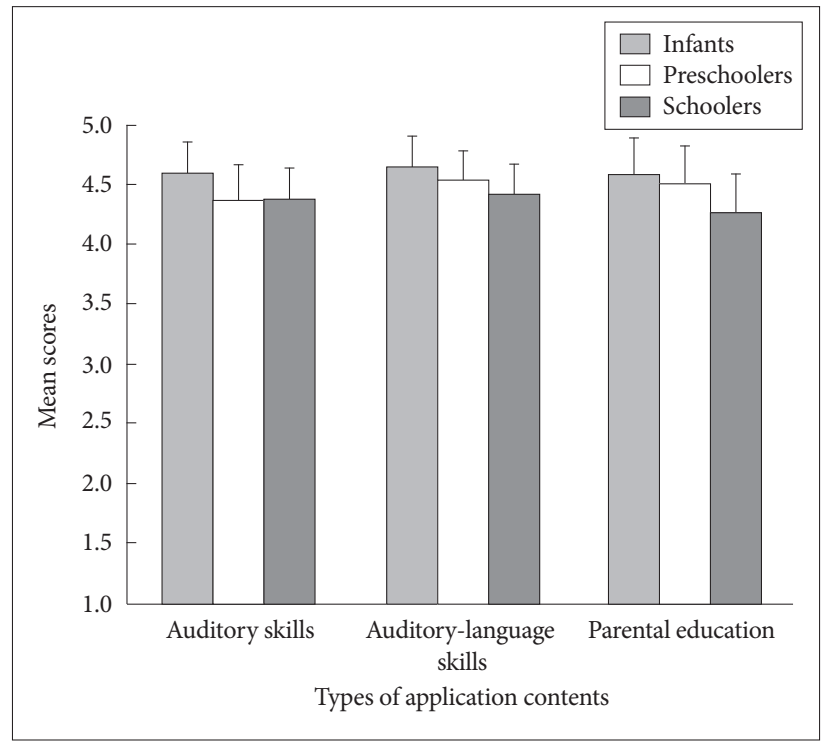

Figure 2. Parents' needs of auditory habilitation contents in smart device application according to three categories (five-point scale with a maximum score of 5).

청각재활 앱 콘텐츠 유형을 ‘청각 기술, '청각-언어 기술, '부 모 교육 및 정보 공유로 세 가지로 나누어서, 청각재활 앱 콘텐 츠에 대해 집단 간 요구에 차이가 있는지 살펴보았다. 그 결과, 영유아에서는 청각-언어 기술 $(\mathrm{M}=4.63, \mathrm{SD}=0.52)$, 청각 기술 $(\mathrm{M}=4.59, \mathrm{SD}=0.50)$, 부모교육 및 정보 공유 $(\mathrm{M}=4.58, \mathrm{SD}=$ $0.60)$, 학령 전기 아동에서는 청각-언어 기술 $(\mathrm{M}=4.52, \mathrm{SD}=$ $0.53)$, 부모교육 및 정보 공유 $(\mathrm{M}=4.50, \mathrm{SD}=0.60)$, 청각 기술 $(\mathrm{M}$ $=4.36, \mathrm{SD}=0.58)$, 학령기 아동에서는 청각-언어 기술 $(\mathrm{M}=$ $4.41, \mathrm{SD}=0.51)$, 청각 기술 $(\mathrm{M}=4.37, \mathrm{SD}=0.51)$, 부모교육 및 정 보 공유( $\mathrm{M}=4.26, \mathrm{SD}=0.66)$ 순서로 나타났다(Figure 2). 청 각재활 콘텐츠 유형에 따른 집단 간 차이가 있는지 살펴보기 위해서 이원혼합분산분석을 실시한 결과, 집단에 따른 주효과 가 유의하지 않게 나타나서 $[\mathrm{F}(2,64)=1.248, p>0.05]$, 연령에 따른 청각재활 앱 요구도에 유의한 차이를 보이지 않았다. 콘텐 츠 유형에 따른 주효과도 유의하지 않아서 $[\mathrm{F}(2,64)=1.714, p$ $>0.05]$, 특정 콘텐츠에 대한 요구도가 높게 나타나지는 않았다. 집단과 콘텐츠 유형에 대한 이차 상호작용 효과도 유의하게 나 타나지 않았다 $[\mathrm{F}(2,64)=1.515, p>0.05]$.

\section{DISCUSSIONS}

현대 사회는 시공간의 제약에서 자유로운 스마트 기기의 광 범위한 보급으로 새로운 미디어 매체가 구축하고 있다. 이러한 환경은 일반인의 삶뿐만 아니라 장애인의 교육, 의료, 재활에도 영향을 미치고 있다. 이 시점에서 본 연구에서는 인공와우 아동 의 부모가 일상생활에서 본인과 자녀를 위해서 스마트 기기를
이용하는 실태를 살펴보고, 인공와우 아동이 스마트 기기를 사 용할 때 부모의 참여도에 대해서 조사하였다. 그리고 임상 현장 과 가정에서 필요로 하는 실제적인 청각재활 앱을 콘텐츠를 개 발하기 위해서 인공와우 아동의 연령대에 따라서 필요로 하는 청각재활 앱 콘텐츠 유형에 차이가 있는지 살펴보고자 하였다.

본 연구에서 설문에 참여한 부모 모두 스마트 기기를 사용하 고 있었으며, $90 \%$ 가 넘는 대다수의 부모가 매일 스마트 기기를 사용하고 있었다. 사용하고 있는 스마트 기기의 종류로는 스마 트폰이 가장 많았으며, 그 다음으로는 태블릿 PC와 스마트 TV 순이었다. 이는 새롭게 등장한 스마트폰은 커뮤니케이션(예, 전 화, 문자, SNS 등)의 기능을 지니면서 휴대가 간편하고 이동성 이 뛰어난 장점 외에도, 기존에 컴퓨터로 하고 있는 정보검색, 커뮤니케이션, 여가, 쇼핑의 기능을 앱을 이용해서 이용할 수 있기 때문에 선호도가 높아졌다고 할 수 있겠다. 부모 중에서 약 58\%는 인공와우 아동의 말지각, 말, 언어 촉진을 위해서 앱 을 사용한 경험이 있었으며, 인공와우 아동의 의사소통 촉진을 위한 앱 정보를 주로 인터넷, 전문가, 앱 마켓, 책을 통해서 얻 고 있었다. 앱을 이용한 중재는 부모가 다양한 프로그램을 스 마트 기기에 쉽게 설치하여 사용할 수 있도록 하는 장점을 지 니고 있다. 하지만, 부모가 사용하는 상당 수의 앱은 전문가에 게 검증을 받지 않은 경우가 대부분이므로, 향후에는 청각재활 전문가가 앱의 교육적 효과를 평가하여 부모가 인공와우 아동 에게 도움이 되는 앱을 사용하도록 해야 할 것이다. 부모의 약 $30 \%$ 는 인공와우 아동에게 앱을 이용한 경험이 없다고 하였으 며, 그 이유는 스마트 기기가 자녀에게 교육적으로 도움이 될지 에 대해서 확신이 들지 않기 때문이라고 보고하였다. 2016년 국 제 보완대체의사소통 학술대회에서 언어치료사, 특수교사, 작 업치료사, 물리치료사 등의 전문가가 장애 성인 및 아동이 사 용할 수 있는 앱을 소개, 평가, 활용 방법 안내하여 정보를 공 유하는 온라인 사이트를 운영한 사례를 발표하기도 하였다 (Buchholz et al., 2016). 이러한 전문가의 활동은 장애 아동과 부모가 부적절한 앱을 사용하는 것을 예방하고, 비전문가가 무 분별하게 교육 및 재활용 앱을 개발하는 것을 막는 자정적인 기 능을 할 수 있을 것으로 생각된다. 청각재활 분야에서도 전문가 가 인공와우 아동의 말지각, 말, 언어 발달에 도움이 되는 앱 콘 텐츠를 개발하는 것뿐만 아니라 개발된 앱에 대해서 평가, 경험 담을 공유할 수 있는 온라인 활동을 한다면, 테크놀로지 발달 에 따른 혜택을 청각재활에서도 누릴 수 있을 것으로 기대해볼 수 있겠다.

부모 대다수가 인공와우 아동(73.1\%)이 스마트 기기를 사용 하는 것에 대해서 허용하고 있는 것으로 나타났다. Ryu(2014) 는 일반 영유아의 스마트폰 사용 비율이 $75.8 \%$ 라고 하였으며, Lee et al.(2013)은 의사소통장애 아동의 스마트 기기 사용 비 
율이 78.29\%라고 하였다. 즉, 부모가 자녀의 장애 유무에 상관 없이 스마트 기기를 허용하는 비율이 높다는 것이다. 이는 그 만큼 스마트 기기의 사용이 보편화되고 있음을 의미하며, 장애 아동도 다양한 기술적 도구를 보편적으로 활용하기 위한 사용 자 관점에서 필요한 기능과 기술을 판별하고 개발할 필요가 있 다는 것을 시사한다. Hwang \& So(2016)는 청각장애 아동을 위한 앱 개발에 인간중심 디자인 방법론이 적용되어야 한다고 언급하면서, 연구자나 개발자가 초기 과정에서 실수요자의 요 구도를 확인하고 최대한 이끌어 내고 개발에 반영해야 한다고 강조한 바 있다. 인간을 중심에 두고 사고하고 인공와우 아동과 부모의 삶에서 아이디어를 도출하여 해결책을 찾아나가는 인 간 중심의 철학의 바탕 위에, 스마트 기기의 연계 기술과 새로 운 기술의 개발이 접목되어 앱 개발이 이루어져야 할 것이다.

부모는 인공와우 아동의 재미를 위해서 원하거나 새로운 것 을 학습하기 위한 목적으로 스마트 기기를 허용하고 있었으며, 인공와우 아동이 부모와의 상호작용 없이 혼자서 스마트 기기 를 사용하는 경우가 높게 나타났다. Lee \& Sung(2012)과 Ryu (2014)의 연구에서도 부모가 자녀의 재미나 학습을 위해서 스 마트 기기를 허용하고 있었으며, 주로 부모가 자녀와 상호작용 하기 힘들거나 육아 피로도 감소를 위해서 자녀가 혼자서 스마 트 기기를 사용하는 것을 허용하는 것으로 보고되었다. 또한, 인공와우 아동의 부모도 자녀의 스마트 기기 사용에 대해서는 허용적이지만, 자녀를 위해 적절한 앱을 검색하는 노력은 적극 적이지 않은 것으로 나타났다. 부모가 인공와우 아동의 스마트 기기 사용할 때의 참여 형태가 자녀가 도움을 요청할 때만 도 와주거나 지켜보는 경우가 높게 나타나서, 부모가 인공와우 아 동 옆에 있을 뿐 실제적으로는 아동이 혼자서 스마트 기기를 조작한다는 것으로 알 수 있었다. 인공와우 아동이 스마트 기 기를 혼자서 조작하는 경향이 높기 때문에, 앱을 이용한 청각 재활의 효과를 높이기 위해서는 인공와우 아동과 부모와의 상 호작용을 고려한 앱의 개발이 필요할 것으로 보인다. 즉, 부모 는 스마트 기기의 앱이 전문가와 부모의 역할을 대체하는 것이 아니며, 보완적이고 효율적으로 인공와우 아동의 의사소통 능 력을 향상시키기 위한 매개체 역할을 한다는 것을 인지해야 할 것이다. 그리고 인공와우 아동을 위한 앱 개발에 관심이 있는 전문가는 인공와우 아동의 의사소통 발달 특성을 고려한 콘텐 츠 개발하는 것과 함께 활용 방안도 제시하는 노력도 기울여야 할 필요가 있겠다.

인공와우 아동의 청각재활용 앱 콘텐츠에 대한 요구도를 살 펴본 결과, 인공와우 아동의 연령대와 청각재활 콘텐츠 유형에 따른 부모의 앱 요구도에 유의한 차이가 나타나지 않았다. 이러 한 결과는 인공와우 아동의 연령에 상관없이 모든 콘텐츠 유형 에 대한 요구도가 높았던 것과 관련되어 있을 것으로 생각된다.
본 연구에서는 영유아, 학령 전기, 학령기 아동 모두에서 청각 기술, 청각-언어 기술, 부모 교육 및 정보 공유의 세 가지 콘텐 츠 유형에 대한 요구도가 평균 4.0 이상으로 높게 나타났었다. 인공와우 아동의 수행력 발달은 인구학적 요인(예, 보청기 착용 시기, 잔존 청력, 인공와우이식 연령 등)과 인지 능력, 청각재활 참여도 등에 따라서 개인 간 차이(individual differences)가 큰 특성을 보이기 때문에(Houston \& Miyamoto, 2010; James et al., 2008; Kirk et al., 2000), 연령 단계보다는 인공와우 아동 의 수행력 발달 수준에 따른 맞춤식의 콘텐츠가 필요하고 이에 따른 부모 교육 지원요구도 높아지기 때문에 나타난 결과로 생 각된다. 고도 이상의 청각장애 아동이 인공와우이식을 하더라 도 정상적인 청력 수준의 질과 양의 청각 정보를 받아들이지 못 하기 때문에(Wilson \& Dorman, 2008), 아동의 연령이 높아 져도 듣기 환경과 학습 내용의 변화에 따라 더 높은 수준의 청 각 기술, 청각-언어 기술이 필요로 하게 된다. 또한, 인공와우 아동의 연령대의 변화에 따라서 말-언어 발달, 학업, 교우관계, 학교생활 적응 등의 새로운 이슈들이 등장하기 때문에, 부모는 인공와우 아동의 연령에 상관없이 지속적인 부모 교육과 정보 공유에 대한 콘텐츠 요구도 높게 나타난 것으로 생각된다. 이는 인공와우 아동을 대상으로 하는 청각재활 임상 현장에서의 부 모의 지원요구가 앱 콘텐츠 요구도에도 그대로 반영된 것으로 보여진다.

본 연구 결과로 인공와우 아동의 부모는 일상생활에서 스마 트 기기를 다양한 매체로 적극적으로 사용하고 있으며 인공와 우 아동의 스마트 기기의 사용도 허용하고 있다는 것을 알 수 있었다. 또한, 본 연구 결과는 부모는 인공와우 아동의 청각재 활용 앱 활용에 대한 관심이 높으며, 스마트 기기를 통한 청각 재활용 앱을 자녀의 의사소통 능력 향상에 도움을 줄 수 있는 도구로 인식하고 있다는 것을 보여준다. 인공와우 아동의 청각 재활용 앱 콘텐츠에 대한 요구도가 높은 만큼, 청각재활 전문 가와 개발자는 인공와우 아동의 말지각, 말, 언어 발달 특성을 고려한 다양한 청각재활 콘텐츠를 개발하는 노력이 필요할 것 이다. 이때, 개인 간 수행력 차이를 보이는 인공와우 아동의 개 별화된 프로그래밍이 가능한 앱이 개발되어 기능적으로 사용 될 수 있도록 하는 방안도 모색되어야 할 것이다. 본 연구는 매 주 청각재활 기관을 방문하여 인공와우 아동의 청각재활을 받 고 있는 부모가 설문조사에 참여했기 때문에, 자녀의 청각재활 에 대한 관심이 높은 부모가 많이 포함되었다는 제한점이 있 다. 그리고 연구 대상이 특정 지역에 제한되어 있어 인공와우 아동의 부모의 전반적인 스마트 기기 경험과 요구도로 일반화 해서 해석하기에 어려운 점이 있다. 향후에는 연구 대상자의 지 역을 균형화하고 배경정보를 다양화한 후속 연구가 필요할 것 이며, 청각재활 전문가에게도 청각재활의 스마트 러닝에 대한 
의견과 경험을 폭넓게 조사할 필요가 있겠다.

중심 단어 : 인공와우·인공와우 착용아동 부모·인공와우 착용 아동·스마트 어플리케이션.

\section{Acknowledgments}

본 연구는 중소기업청의 기술혁신개발사업의 일환으로 수행하였 음(S23613030, 말, 언어가 늦은 아동을 위한 음성인식 기반 의사소 통 훈련 서비스 시스템 개발).

\section{REFERENCES}

American Speech-Language-Hearing Association (AHSA). (2016, October 15). Cochlear implants. Retrieved from http://www.asha.org/uploadedFiles/AIS-Cochlear-Implants.pdf\#search=\%22cochlear\%22.

Buchholz, M., Muller, I. M., \& Derbring, S. (2016). Apps for communication: Projects and user cases. International Society for Augmentative and Alternative Communication, August 6-13 2016, Toronto, Canada.

Cole, F. B. \& Flexer, C. (2011). Hearing aids, cochlear implants, and FM system. In F. B. Cole \& C. Flexer (2nd ed.). Children with Hearing Loss Developing Listening and Talking: Birth to Six (pp. 117-166). United Kingdom, OX: Plural Press.

Faul, F., Erdfelder, E., Buchner, A., \& Lang, A. G. (2009). Statistical power analyses using $\mathrm{G}^{*}$ Power 3.1: Tests for correlation and regression analyses. Behavior Research Methods, 41(4), 1149-1160.

Fu, Q. J. \& Galvin, J. J. III. (2007). Computer-assisted speech training for cochlear implant patients: Feasibility, outcomes, and future directions. Seminar in Hearing, 28(2), 142-150.

Houston, D. M. \& Miyamoto, R. T. (2010). Effects of early auditory experience on word learning and speech perception in deaf children with cochlear Implants: Implications for sensitive periods of language development. Otology and Neurotology, 31(8), 1248-1253.

Hwang, G. W. \& So, H. J. (2016). Developing a mobile application to learn Korean for children with hearing impairment-human-centered design approach. AAC Research and Practice, 4(1), 101-123.

Im, H., Song, J. Y., Cho, Y. K., Kim, Y. J., Kim, H. J., \& Kang, Y. J. (2013). The use of smartphone applications in stroke rehabilitation in Korea. Brain and Neurorehabilitation, 6(1), 33-40.

James, D., Rajput, K., Brinton, J., \& Goswami, U. (2008). Phonological awareness, vocabulary, and word reading in children who use cochlear implants: Does age of implantation explain individual variability in performance outcomes and growth? Journal of Deaf Studies and Deaf Education, 13(1), 117-137.

Kirk, K. I., Miyamoto, R. T., Ying, E. A., Perdew, A. E., \& Zuganelis, H. (2000). Cochlear implantation in young children: Effects of age at implantation and communication mode. Volta Review, 102(4), 127-144.

Korea Information Society Development Institute. (2011). Analysis of using smart devices. Gwacheon: Korea Information Society Development Institute.

Korea Internet and Security Agency. (2015). Survey of using smartphone in 2015. Seoul, Korea.

Kwak, N. U. \& Lim, E. J. (2013). Development and analysis of scale for parents to verify the extent of early childhood's use of smart devices. The Journal of Korea Elementary Education, 24(4), 183-201.

Lee, H. J., Kang, M. K., \& Kim, Y. T. (2013). Current practice and support needs in smart media perceived by the mothers of children with communication difficulties. Communication Sciences and Disorders, 18(2), 163-171.

Lee, H. R. \& Lee, S. (2014). Parent survey on the effects of digital instrument on the language development in Korean children. Communication Sciences and Disorders, 19(2), 178-190.

Lee, M. Y. (2008). Diagnostic therapy for infants with hearing impairment. The 5th Dong-A Hearing Symposium. Busan, Korea.

Lee, S. G. \& Lee, Y. (2016). The effects of auditory intervention using smartphone application on auditory memory in children with cochlear implants. The 30th Korean Academy of Speech-Language Pathology and Audiology Conference. Seoul, Korea.

Lee, W. \& Sung, W. (2012). Mother's perceptions of their preschool children's smartphone use. Korean Journal of Child Care and Education Policy, 6(6), 20-38.

Lee, W. H. (2010). A study on the current status and invigoration plan of education contents for smart TV (unpublished master's thesis). Yeungnam University, Daegue.

Lee, Y., Lee, S., \& Sung, M. (2015). Analysis of mobile application trends for speech and language therapy of children with disabilities in Korea. Journal of the Korean Society of Speech Sciences, 7(3), 153-163.

Lim, J. H. \& Park, E. H. (2012). Development and research trends of application as the smart education media for ASD. Journal of the Korean Association for Persons with Autism, 12(1), 93-117.

Nakeva von Mentzer, C., Lyxell, B., Sahlén, B., Dahlström, Ö., Lindgren, M., Ors, M., et al. (2014). Computer-assisted reading intervention with a phonics approach for children using cochlear implants or hearing aids. Scandinavian Journal of Psychology, 55(5), 448-455.

Nakeva von Mentzer, C. N., Lyxell, B., Sahlén, B., Wass, M., Lindgren, M., Ors, M., et al. (2013). Computer-assisted training of phoneme-grapheme correspondence for children who are deaf and hard of hearing: Effects on phonological processing skills. International Journal of Pediatric Otorhinolaryngology, 77(12), 2049-2057.

Nikolopoulos, T. P., Archbold, S., \& McCormick, B. (2003). Current trends in pediatric cochlear implantation. In B. McCormick \& S. Archbold (Eds.). Cochlear Implants for Young Children (2nd ed.). Philadelphia, PA: Whurr Publishers.

Ryu, M. H. (2014). A study of infants/toddlers' use of smartphones and their Mothers' perceptions on smartphone using. The Korea Association of Child Care and Education, 86, 307-329.

Wilson, B. S. \& Dorman, M. F. (2008). Cochlear implants: Current designs and future possibilities. Journal of Rehabilitation Research and Development, 45(5), 695-730.

Yim, D., Kim, S. Y., Park, W., Cheon, S., \& Lee, Y. J. (2014). Analysis on needs based survey of parents and speech-language pathologists for smartphone programs. Communication Sciences and Disorders, 19(4), 486-500.

Yu, J., Chun, H., Song, C. G., \& Han, W. (2014). Case study of speech perception enhancement in hearing-impaired adult by auditory training program of mobile device. Audiology, 10(2), 158-168. 


\section{APPENDIX}

\section{I. 부모님의 스마트 기기 이용실태}

현재 사용하고 있는 스마트 기기에는 어떤 것이 있습니까? (복수응답 가능)

스마트폰

테블릿 PC(예, 아이패드, 갤럭시 탭 등)

스마트 TV

기타:

2. 스마트 기기를 사용하는 목적은 무엇입니까? (복수응답 가능)

$\square$ 정보 검색(뉴스, 여행, 맛집, 부동산, 건강 정보 등)

$\square$ 교육 및 학습(인터넷 강의, 사전 등)

$\square$ 커뮤니케이션(카카오톡, 카카오스토리, 페이스북, 네이버 밴드, 음성전화 등)

$\square$ 업무(문서 확인/ 작업)

$\square$ 여가(사진/동영상 촬영, TV/동영상 시청, 게임, 음악 청취)

$\square$ 위치기반 서비스(네비게이션, 대중교통 도착 확인 등)

쇼핑(상품/티켓 구매, 할인쿠폰, 기프티콘 등)

금융서비스(뱅킹, 주식거래 등)

기타:

3. 스마트 기기를 주로 이용하는 장소는 어떻게 되십니까? (복수응답 가능)

$\square$ 가정(집)

직장(회사)

$\square$ 자녀의 교육기관(학교, 학원, 언어치료실 등)

$\square$ 이동 중인 교통수단 안에서

$\square$ 상업시설(커피숍, 식당, 쇼핑몰 등)

실외장소(길거리, 공원 등)

공공시설(관공서, 도서관 등)

\section{II. 자녀의 스마트 기기 이용에 대한 어머니의 참여}

자녀가 스마트 기기를 사용합니까?

$\square$ 예

$\square$ 아니오

2. 자녀에게 스마트 기기를 사용하게 한다면, 그 이유는 무엇입니까? (복수응답 가능)

자녀가 원해서

$\square$ 짜증내는 자녀를 달래기 위해서

자녀가 어머니의 일을 방해하지 않도록 하기 위해서

자녀의 교육/학습을 위해서

기타: 
3. 자녀에게 스마트 기기를 사용하지 않게 한다면, 그 이유는 무엇입니까? (복수응답 가능)

$\square$ 스마트 기기가 자녀에게 좋지 않을 것 같아서

$\square$ 자녀가 스마트 기기를 좋아하지 않아서

$\square$ 기타: :

III. 청각재활 프로그램 및 콘텐츠 요구도

1. 자녀의 듣기 능력 향상을 위한 스마트 기기 앱(활동)이 개발된다면 교육효과가 있을 것으로 생각하십니까?

$\square$ 예

$\square$ 아니오

※ 아래 내용을 잘 읽고, 자녀에게 필요한 앱(프로그램/활동)에 대한 필요성에 대해서 체크( $\checkmark$ 를 해주시기 바랍니다.

\begin{tabular}{|c|c|c|c|c|c|c|}
\hline 번호 & 문 & $\begin{array}{l}\text { 전혀 } \\
\text { 필요 } \\
\text { 없다 }\end{array}$ & $\begin{array}{l}\text { 필요 } \\
\text { 없다 }\end{array}$ & $\begin{array}{l}\text { 보통 } \\
\text { 이다 }\end{array}$ & $\begin{array}{l}\text { 필요 } \\
\text { 하다 }\end{array}$ & $\begin{array}{l}\text { 매우 } \\
\text { 필요 } \\
\text { 하다 }\end{array}$ \\
\hline 2 & 그림, 애니메이션, 효과음 등과 함께 환경음을 들려주는 콘텐츠 & & & & & \\
\hline 3 & 어휘(명사, 동사 등)가 그림, 애니메이션, 효과음과 제시되는 콘텐츠 & & & & & \\
\hline 4 & 청각기억력을 향상시킬 수 있는 콘텐츠 & & & & & \\
\hline 5 & 다양한 소음을 말소리(단어, 문장, 긴 글)와 함께 들려주는 콘텐츠 & & & & & \\
\hline 6 & 청력검사, 매핑을 원활하게 하기 위한 소리-반응을 연습하는 콘텐츠 & & & & & \\
\hline 7 & 말소리를 듣고 반응하게 하여 어휘를 학습할 수 있는 콘텐츠 & & & & & \\
\hline 8 & 이야기를 듣고 이해하여 질문에 대답하는 콘텐츠 & & & & & \\
\hline 9 & 일상생활에서 자주 사용하는 문장을 익힐 수 있는 콘텐츠 & & & & & \\
\hline 10 & 읽기 자료를 음성으로 들을 수 있게 지원해주는 콘텐츠 & & & & & \\
\hline 11 & 자녀의 듣기 교육과 관련된 전문적인 강의를 제공하는 콘텐츠 & & & & & \\
\hline 12 & 자녀의 듣기 교육과 관련된 부모 교육을 제공하는 콘텐츠 & & & & & \\
\hline 13 & 자녀의 듣기 능력과 관련하여 전문가 간 정보를 공유할 수 있는 콘텐츠 & & & & & \\
\hline
\end{tabular}

14. 위에 제시된 콘텐츠 외에도 자녀의 듣기 능력 발달을 위해서 개발되기를 희망하는 콘텐츠를 적어주세요. 